\title{
Interferon-gamma increases monocyte PD-L1 but does not diminish T-cell activation
}

\author{
Norman Galbraith ${ }^{1}$, Samuel Walker ${ }^{2}$, Sarah Gardner ${ }^{3}$, Campbell Bishop ${ }^{3}$, Susan \\ Galandiuk ${ }^{3}$, and Hiram Polk ${ }^{3}$ \\ ${ }^{1}$ Royal Alexandra Hospital \\ ${ }^{2}$ University of Kentucky \\ ${ }^{3}$ University of Louisville School of Medicine
}

May 5, 2020

\begin{abstract}
Immune dysfunction can occur during sepsis or following major trauma. Decreased monocyte HLA-DR expression and cytokine responses are associated with mortality. Recent studies have shown that adaptive immune system defects can also occur in in such patients, characterised by increased PD-L1 expression and associated T-cell anergy. The aim of this study was to determine the effects of an immune adjuvant, interferon-gamma, on monocyte PD-L1 expression and T-cell activation in an ex-vivo human whole blood model of infection. We found that with interferon-gamma treatment, monocytes had increased HLA-DR expression and augmented TNF- $\alpha$ production in response to LPS stimulation. Both LPS and interferon-gamma increased the level of monocyte PD-L1 expression, and that a combination of both agents synergistically stimulated a further increase in PD-L1 levels as measured by flow cytometry. However, despite elevated PD-L1 expression, both CD4 and CD8 T-cell activation was not diminished by the addition of interferon-gamma treatment. These findings suggest that PD-L1 may not be a reliable marker for T-cell anergy, and that interferon-gamma remains an adjuvant of interest that can improve the monocyte inflammatory response while preserving T-cell activation.
\end{abstract}

\section{Introduction}

Trauma and sepsis remain a major cause of mortality [1]. Early recognition and prompt intervention with supportive measures and improvements in critical care environments have led to some improvement in mortality rates [2]. However, many patients now survive the initial acute phase of treatment, but are left with a prolonged hospital stay, riddled with infective complications [3]. Such a major physiological insult may be the cause of immune dysfunction, which leaves patients susceptible to secondary infections [4-6]. There is now evidence demonstrating that even up to 3 years following the initial insult, patients have persisting immune defects and chronic illness associated with their critical care [7].

This form of immune dysfunction, or tolerance, to microbial danger and pathogen-associated molecular patterns (DAMPs and PAMPs) is characterized by impaired monocyte function [8]. Evidence shows that in response to infection, surgical patients have a downregulation of the toll-like receptor pathway as well as the Inhibitor of Kappa B and Nuclear Factor Kappa B pathways, resulting in impaired immune responses. Decreased monocyte HLA-DR expression and decreased TNF- $\alpha$ production in response to ex-vivo LPS stimulation are both associated with increased nosocomial infections and death in many patients following trauma or sepsis $[5,8]$. 
Various prospective studies have trialed interferon-gamma (IFN- $\gamma$ ) with a goal of restoring monocyte function and improve morbidity or mortality. Such evidence has shown recovery of monocyte function as well as a reduction in re-operations for infection, decreased infection-related deaths and ventilation-associated pneumonia [9-12] However, consistent improvements in mortality in such patients have not been demonstrated and thus IFN- $\gamma$, like many other immunoadjuvants, have not succeeded in altering clinical practice [13].

The reasons for a failure to demonstrate benefit may be related to trial design and suboptimal timing and dosing of IFN- $\gamma$, or may be related to patient selection (i.e. patients included regardless of monocyte function) [14]. On closer inspection of the clinical trials, it is apparent that the benefit of IFN- $\gamma$ treatment to monocyte function was present for the duration of treatment. However, on cessation of IFN- $\gamma$ treatment, a rebound impairment of monocyte function was observed.

An important factor influencing the success of these trials may be the incomplete understanding of mechanisms of pleiotropic agents such as IFN- $\gamma$ may have on other aspects of our redundant, evolved immune system. Trauma and sepsis affect not only the innate immune cells but also the adaptive immune system [15-17]. In response to such a stimulus, increased PD-1 expression occurs on T-cells, NK cells and B cells $[18,19]$. Its ligand, PD-L1, is increased on monocytes, macrophages, dendritic cells and neutrophils [20, 21]. Increases in monocyte PD-L1 expression correlates with impaired monocyte function, increased sequential organ failure assessment scores and are predictive of death during septic shock [22-25].

Such changes in this acute setting are thought to be analogous to changes in the microenvironment in cancer $[7,26]$. The activation of the PD-1/PD-L1 pathway causes lymphocyte exhaustion and apoptosis, which may impair cellular function and bacterial clearance. The consequent T-cell dysfunction associated with PD-1/PD-L1 upregulation is associated with septic shock and increased mortality [27, 28]. Animal models of sepsis have shown that ligation of this pathway improves survival, suggesting that the modulation of the PD-1/PD-L1 pathway may be important in governing T-cell function [29-32].

Current thinking for immunotherapy for the critically ill patient is to individualize adjunctive therapy depending on the specific biomarker-driven immunopathologic phenotype of the patient [33], as exemplified by IFN- $\gamma$ for the patient with monocyte impairment and/or an anti-PD-L1 or IL-7 agent for the patient with T-cell anergy and apoptosis [34]. However, these are overlapping phenomena and understanding how immunotherapy agents influence the multiple facets of the immune response is critical in developing effective trials in the critically ill.

The purpose of this study was to examine IFN- $\gamma$ in an ex-vivo model of infection to determine the effect of IFN- $\gamma$ on monocyte PD-L1 expression and determine its influence on T-cell function.

\section{Materials and methods}

\section{Human blood sample preparation}

Venous blood was collected from healthy volunteers using EDTA vacutainers (Becton Dickinson, Franklin Lakes, NJ) following informed consent. The study was approved by the University of Louisville Institutional Review Board (08.018). Volunteers were excluded for the presence of chronic illness, use of anti-inflammatory or immunosuppressive medications or signs of acute illness. Whole blood was aliquoted in $1 \mathrm{~mL}$ volumes in Falcon polypropylene culture tubes (Fisher Scientific, Waltham, MA). Samples were incubated for up to 18 hours in various conditions at $37^{\circ} \mathrm{C}$ with $5 \%$ carbon dioxide and gentle vortexing every 4 hours. After $18 \mathrm{~h}$, whole blood was centrifuged at $3000 \mathrm{RPM}$ for 3 minutes to obtain plasma which was stored at $-80^{\circ} \mathrm{C}$ until later analysis. Prior work determined optimal sample timing [35].

\section{Whole blood stimulation}

Blood samples were either unstimulated (control), or stimulated with $100 \mathrm{ng} / \mathrm{mL}$ of lipopolysaccharide (LPS, from Escherichia coli 0111:B4, Sigma-Aldrich, St. Louis, MO), IFN- $\gamma$ (Sigma Aldrich, St. Louis, MO) or a combination of both. The IFN- $\gamma$ dose $(100 \mathrm{ng} / \mathrm{mL})$ was chosen based on prior experiments [36].

\section{Cytokine analysis}


Stored plasma was used to determine cytokine concentrations using Enzyme-linked immunosorbent assays (ELISAs) according to the manufacturer's protocol (eBioscience, San Diego, CA). Samples were measured in duplicate and compared against a known standard curve. The lower limits of detection were $2 \mathrm{pg} / \mathrm{mL}$ and $4 \mathrm{pg} / \mathrm{mL}$ for IL-10 and TNF- $\alpha$, respectively.

\section{Flow cytometry}

Whole blood samples of $50 \mu \mathrm{L}$ were stained with fluorescein isothiocyanate (FITC)-labeled antihuman CD14 and either phycoerythrin (PE)-labeled anti-HLA-DR or anti-PD-L1 antibodies (BD Biosciences, La Jolla, $\mathrm{CA}$ ). After 25 mins of staining at $4^{\circ} \mathrm{C}$, erythrocyte lysis was achieved with ammonium chloride, potassium bicarbonate, and EDTA (Sigma Chemical Co., St. Louis, MO) for 6 min. Cells were then washed with Dulbecco Phosphate Buffered Saline (DPBS) (Sigma Chemical Co., St. Louis, MO) and fixed in $300 \mu \mathrm{L}$ of $1 \%$ paraformaldehyde.

For flow cytometric analysis, samples were analyzed using a FACSCalibur flow cytometer (Becton Dickinson, San Diego, CA) within 48 hours of venipuncture. A minimum of 20,000 events were acquired and mean fluorescence intensity (MFI) analyzed using Cell Quest software (Becton Dickinson, San Diego, CA). Appropriate isotype controls were used for each antibody to check for non-specific binding (BD Biosciences, La Jolla, CA).

\section{T-cell activity assay}

After whole blood was treated in the conditions as described under Human Blood Sample Preparation for 16 hours, the blood samples were transferred to $50 \mathrm{~mL}$ tubes with Hypaque Ficoll (Invitrogen, Carlsbad, CA), and then centrifuged at $1500 \mathrm{x}$ g for $30 \mathrm{~min}$. The buffy coat interface was carefully removed by pipetting and the residue washed with DPBS twice. Peripheral blood mononuclear cells (PBMCs) were then manually counted by microscopy and viability checked with Trypan Blue staining. Culture medium consisted of RPMI 1640 (Sigma Aldrich, St Louis, MO) which was supplemented with 10\% fetal bovine serum, L-glutamine, and antibiotic/antimycotic agents (Thermo Fisher Scientific, Waltham, MA) at a concentration of $5 \times 10^{6}$ cells/mL. PBMC's were cultured in a 24 well plate (Costar, Corning, NY). Cells were then stimulated with a pre-mixed cocktail of Phorbol myristate acetate (PMA), Ionomycin and Brefeldin A (Leukocyte Activation Cocktail with BD Golgiplug BD Biosciences, La Jolla, CA) for 6 hours. After stimulation, cells were incubated with either FITC-conjugated CD4 or CD8 antibodies (BD Biosciences, La Jolla, CA) for 20 min and fixed with $300 \mu \mathrm{L}$ of $1 \%$ formalin at $4^{\circ} \mathrm{C}$. Following fixation, cells were permeabilized with $10 \%$ methanol for $1 \mathrm{~h}$, stained for PE-conjugated IFN- $\gamma$ antibodies or the appropriate IgG1 isotype control (eBioscience, San Diego, CA) for 30 min and then analyzed by flow cytometry as described above.

\section{Statistical Analysis}

Data were analyzed using Repeated-measures analysis of variance testing to detect significant differences in corresponding differences within donors. Post-hoc multiple comparison testing was undertaken using HolmsSidak test to isolate differences between conditions. Data are expressed as mean \pm S.E.M. Significance was set at $\mathrm{p}<0.05$. Statistical analysis was undertaken using GraphPad Prism 6.0 (La Jolla, CA).

\section{Results}

\section{Cytokine production}

In this whole blood system, stimulation with $100 \mathrm{ng} / \mathrm{mL}$ of LPS increased the TNF- $\alpha$ concentration of 29.86 $( \pm 11.88) \mathrm{pg} / \mathrm{mL}$ compared with $11.95( \pm 9.05) \mathrm{pg} / \mathrm{mL}$ under control conditions $(\mathrm{p}=0.032)$ (Fig. 1$)$. LPS increased IL-10 production compared with control conditions $(\mathrm{p}=0.001)$, but IFN- $\gamma$ alone had no significant effect on either TNF- $\alpha$ or IL-10 levels.

However, the addition of IFN- $\gamma$ treatment to LPS stimulation led to further increases in TNF- $\alpha$ concentrations, reaching $138.41( \pm 49.46) \mathrm{pg} / \mathrm{mL}(\mathrm{p}=0.0386)$ (Fig. 1). Conversely, when IFN- $\gamma$ was added to LPS 
treated blood, IL-10 was significantly decreased $(\mathrm{p}=0.001)$. This was similar to the levels observed in the control conditions.

\section{HLA-DR expression}

In control conditions, monocyte HLA-DR expression remained low throughout the time points measured (Fig. 2). LPS increased monocyte HLA-DR expression to $1190.27( \pm 178.73)$ MFI at $6 \mathrm{~h}(\mathrm{p}=<0.001)$ and this remained similarly elevated at $18 \mathrm{~h}$ when compared with control $(\mathrm{p}=0.006)$.

IFN- $\gamma$ treatment alone did not affect HLA-DR expression at $6 \mathrm{~h}$, and by $18 \mathrm{~h}$ expression was higher than control conditions but still only $521.89( \pm 76.01)$ MFI $(\mathrm{p}=0.243)$.

Treatment with IFN- $\gamma$ with LPS demonstrated similarly elevated monocyte HLA-DR expression at $6 \mathrm{~h}$ as LPS treatment alone $(\mathrm{p}=0.843)$. However, at $18 \mathrm{~h}$ monocyte HLA-DR expression was significantly higher than with LPS without IFN- $\gamma(\mathrm{p}=0.018)($ Fig. 2).

\section{PD-L1 expression}

Monocyte PD-L1 expression, as measured by flow cytometry, is illustrated in Figure 3. Under control conditions, PD-L1 expression remained low throughout the $18 \mathrm{~h}$ duration. Interestingly, both the addition of either LPS or IFN- $\gamma$ led to similar increases in monocyte PD-L1. Under both conditions, PD-L1 expression reached $76.05( \pm 14.2)$ and $85.71( \pm 15.7)$ MFI, respectively, both higher than control conditions at $18 \mathrm{~h}(\mathrm{p}$ $=0.020$ and $\mathrm{p}=0.012$, respectively).

The combination of LPS and IFN- $\gamma$ led to an early synergistic increase in monocyte PD-L1 expression at 6 $\mathrm{h}$, higher than with either alone ( $\mathrm{p}=<0.0001$ for both comparisons). By $18 \mathrm{~h}$, further increases in PD-L1 expression were observed reaching $203.39( \pm 29.3) \mathrm{MFI}$, again, higher than either LPS or IFN- $\gamma$ alone $(\mathrm{p}=$ $<0.001$ for both comparisons).

\section{T-cell function}

For each of the 4 conditions (control, LPS, IFN- $\gamma$, LPS plus IFN- $\gamma$ ), the level of T-cell activation in both CD4 and CD8 lymphocytes was measured (Fig. 4). In CD4 T-cells, the level of intracellular IFN- $\gamma$ production increased in stimulated blood in control conditions, as compared with unstimulated blood $(\mathrm{p}=<0.001)$. However, the addition of $100 \mathrm{ng} / \mathrm{ml}$ LPS led to decreased CD4 activation $(\mathrm{p}=0.029)$. IFN- $\gamma$ treatment alone did not influence CD4 activation compared with control conditions. No differences were seen in CD4 T-cells with a combination of LPS and IFN- $\gamma$ treatment, compared with LPS treatment alone.

In CD8 T-cells, a large increase in T-cell activation was seen in stimulated control cells compared with unstimulated conditions. Again, $100 \mathrm{ng} / \mathrm{mL}$ LPS decreased T-cell activation with the percentage of IFN$\gamma$-producing CD8 T-cells declining from $15.67( \pm 4.05) \%$ to $9.25( \pm 4.06) \%(\mathrm{p}=0.004)$. The addition of IFN- $\gamma$ alone did not lead to any change in CD8 T-cell activation as compared to the control condition. The addition of both IFN- $\gamma$ and LPS conditions did not further affect the level of CD8 T-cell activation. This was comparable to the $9.25( \pm 4.05) \%$ of activated CD8 T-cells seen with LPS alone.

\section{Discussion}

Immune dysfunction is an important facet of poor bacterial clearance and secondary infection in the critically ill surgical patient. The failure to orchestrate an effective immune response is a result of both impaired innate and adaptive systems [15]. Interferon- $\gamma$ has been frequently studied as an adjuvant in surgical patients to correct monocyte impairment [14]. However, the effect of interferon- $\gamma$ on the adaptive system, and in particular, upon the PD-1-PD-L1 pathway involved in lymphocyte anergy, is not fully understood.

Our data demonstrate agreement that an endotoxin challenge leads to an increase in both the pro- and anti-inflammatory cytokine response and leads to activation of monocytes with increased HLA-DR expression. Interferon- $\gamma$ treatment of LPS-exposed leukocytes promoted an "M1" pro-inflammatory phenotype, by causing further increases in TNF- $\alpha$ with a reciprocal decrease in the anti-inflammatory cytokine IL- 10 . Monocyte function appeared to improve with an augmented HLA-DR expression, a representative marker of 
antigen presentation. These findings are in keeping with many previous studies on the effects of interferon- $\gamma$ $[9,10,36-39]$.

The presence of endotoxin stimulated the increase of monocyte PD-L1 expression. Although interferon- $\gamma$ improved monocyte function, it synergistically increased PD-L1 levels beyond that of the levels associated with LPS alone. This is consistent with previous studies [36, 40]. This increase in PD-L1 expression despite apparent improvements in monocyte function conflicts with the concept of PD-L1 acting as a marker of monocyte dysfunction. Despite this increase in monocyte PD-L1, a marker previously associated with monocyte impairment and worse clinical outcomes, we found that T-cell function was preserved with interferon- $\gamma$ treatment. This finding is in keeping with clinical observations of T-cell reactivity in patients undergoing interferon- $\gamma$ treatment in the context of both trauma and elective gastrointestinal surgery [41].

In original trauma studies, there appeared to be a "rebound" of decreased monocyte function after the cessation of adjuvant interferon- $\gamma$. We hypothesized that this may be due an unrecognized PD-L1 induction, resulting in T-cell dysfunction and decreased endogenous interferon- $\gamma$ as a mechanism for this treatment failure. However, our findings that elevated PD-L1 does not appear to reflect impaired lymphocyte function, with preserved endogenous interferon- $\gamma$ responses, likely dispels this concern.

These findings are interesting mechanistically. One explanation may be that interferon- $\gamma$ leads to increased TNF- $\alpha$, and that the upregulated PD-L1 may in fact be a result of the TNF- $\alpha$ levels, rather than a direct effect of interferon- $\gamma$. A previous study has shown that culture with recombinant TNF- $\alpha$ increases monocyte PD-L1, which in turn can be prevented with TNF- $\alpha$ inhibition [42]. More recently, a study of various cell types found that both TNF- $\alpha$ and IFN- $\gamma$ synergistically increased PD-L1 expression, but then through induction of a miR-155 negative feedback loop, PD-L1 levels were then suppressed [43].

The cellular and clinical effects of interferon- $\gamma$ in experimental and clinical scenarios relating to the surgical patient are summarized in Figure 5. Although this list is not exhaustive, both established as well as recent findings of the effects of interferon- $\gamma$ are highlighted. This includes effects on both the adaptive as well as the innate immune system. Although interferon- $\gamma$ therapy upregulates PD-L1 expression on circulating and fixed leukocytes, there is not a deleterious effect on lymphocyte function. Given the increasing body of evidence toward T-cell anergy and exhaustion in patients suffering from trauma and sepsis, the addition of interferon- $\gamma$ does not appear to exacerbate this important defect. A recent study of interferon- $\gamma$ therapy given to septic patients with low monocyte HLA-DR expression demonstrated equivalent lymphocyte populations after adjuvant treatment, other than a non-significant decrease in NK cell numbers [44]. Many groups have moved away from developing therapies targeting monocyte function, with a current focus on the role of checkpoint inhibitors to reverse immune dysfunction. Recent randomized controlled trials using IL-7 and anti-PD-L1 therapies to correct T-cell defects appear well tolerated, with the latter study also appearing to restore monocyte HLA-DR [45, 46]. Our findings highlight that labelling PD-L1 as the critical link from monocyte to lymphocyte dysfunction during septic immunopathology may be oversimplifying such a complex leukocyte interaction. Furthermore, given that our results demonstrate that interferon- $\gamma$ increases PD-L1 expression but does not impact on T-cell function, our study sets the scene for potential combination strategies with interferon- $\gamma$ complimenting anti-PD-L1 therapy.

This study has some limitations. It presents a small and narrowly-focused set of experiments to address specific questions about feedback mechanisms of potential interferon- $\gamma$-based therapy. Murine models of sepsis often fail to translate to humans effectively and single-cell culture does not preserve the important interaction among immune cells, and in particular, innate and adaptive systems [47]. While this whole blood model allows for the study of the milieu of diverse cellular subsets, it does not account for the role of fixed, non-circulating leukocytes such as those in the hepatic and splenic compartments. Due to the ex-vivo nature of whole blood, study beyond the 18 hour time period cannot be relied upon due to concerns about cell viability beyond this time point. Finally, LPS was used to represent the bacterial challenge with which cells were stimulated. Many surgical patients will sustain gram negative bacteraemia due to a primary gastrointestinal source of infection or endotoxin translocation in the critically ill patient [48]. Some evidence has shown that the human genomic response to LPS largely overlaps with that of trauma, sepsis and even 
burn injury [15]. Nevertheless, the in-vivo response to bacterial DAMPs and PAMPs and from polymicrobial infection will presumably be more complex than this study represents. Nevertheless, this established model accounts for some of the human variability in responses between donors. It is static and reproducible in its findings.

We conclude that in the context of endotoxin-stimulated whole blood, interferon- $\gamma$ not only improves monocyte function, but also increases monocyte surface PD-L1 expression. However, despite increases in PD-L1 expression, T-cell function is not affected. This could be reassuring for clinician-scientists re-considering the use of interferon- $\gamma$ as an adjuvant in critically ill patients, and these findings expand the knowledge on the role of PD-L1 in the growing field of immune checkpoint inhibition in sepsis-related immunopathology.

\section{Acknowledgements}

N.J.G designed the experiments, performed the experiments, analysed the data and drafted the manuscript. S.P.W. and C.B. and contributed to the experimental work. S.G. and H.C.P. revised the manuscript critically for important intellectual content. S.A.G. contributed to the experimental work and revised the manuscript critically for important intellectual content. N.J.G., H.C.P. and S.G. contributed to the conception of the study, design of experiments, supervised the experimental work and revision of the manuscript critically for important intellectual content. All authors approved the manuscript.

\section{Funding}

This work was supported by the John W. Price and Barbara Thruston Atwood Price Trust and by the James and Emmeline Ferguson Research Fellowship Trust. We would like to acknowledge the Mary K. Oxley Foundation and by the Dizney Family Foundation who also provided support.

\section{Competing interests}

None of the authors has any disclosures or competing interests.

\section{Data availability statement}

The datasets generated during and/or analysed during the current study are available from the corresponding author on reasonable request.

We have reviewed the Ethical Policies of the Journal and believe that our submission complies with them.

\section{References}

1. Sauaia A, Moore FA, Moore EE. Postinjury Inflammation and Organ Dysfunction. Critical care clinics $2017 ; 33: 167-91$.

2. Levy MM, Rhodes A, Phillips GS, Townsend SR, Schorr CA, Beale R, Osborn T, Lemeshow S, Chiche JD, Artigas A, Dellinger RP. Surviving Sepsis Campaign: association between performance metrics and outcomes in a 7.5-year study. Critical care medicine $2015 ; 43: 3-12$.

3. Efron PA, Mohr AM, Bihorac A, Horiguchi H, Hollen MK, Segal MS, Baker HV, Leeuwenburgh C, Moldawer LL, Moore FA, Brakenridge SC. Persistent inflammation, immunosuppression, and catabolism and the development of chronic critical illness after surgery. Surgery 2018;164:178-84.

4. Kirchhoff C, Biberthaler P, Mutschler WE, Faist E, Jochum M, Zedler S. Early down-regulation of the pro-inflammatory potential of monocytes is correlated to organ dysfunction in patients after severe multiple injury: a cohort study. Crit Care 2009; 13 :R88.

5. Cheron A, Floccard B, Allaouchiche B, Guignant C, Poitevin F, Malcus C, Crozon J, Faure A, Guillaume C, Marcotte G, Vulliez A, Monneuse O, Monneret G. Lack of recovery in monocyte human leukocyte antigenDR expression is independently associated with the development of sepsis after major trauma. Crit Care 2010; 14 :R208. 
6. Boomer JS, To K, Chang KC, Takasu O, Osborne DF, Walton AH, Bricker TL, Jarman SD, 2nd, Kreisel D, Krupnick AS, Srivastava A, Swanson PE, Green JM, Hotchkiss RS. Immunosuppression in patients who die of sepsis and multiple organ failure. Jama 2011; $306: 2594-605$.

7. Horiguchi H, Loftus TJ, Hawkins RB, Raymond SL, Stortz JA, Hollen MK, Weiss BP, Miller ES, Bihorac A, Larson SD, Mohr AM, Brakenridge SC, Tsujimoto H, Ueno H, Moore FA, Moldawer LL, Efron PA. Innate Immunity in the Persistent Inflammation, Immunosuppression, and Catabolism Syndrome and Its Implications for Therapy. Frontiers in immunology 2018;9:595.

8. Biswas SK, Lopez-Collazo E. Endotoxin tolerance: new mechanisms, molecules and clinical significance. Trends Immunol 2009;30:475-87.

9. Docke WD, Randow F, Syrbe U, Krausch D, Asadullah K, Reinke P, Volk HD, Kox W. Monocyte deactivation in septic patients: restoration by IFN-gamma treatment. Nat Med 1997; 3 :678-81.

10. Nakos G, Malamou-Mitsi VD, Lachana A, Karassavoglou A, Kitsiouli E, Agnandi N, Lekka ME. Immunoparalysis in patients with severe trauma and the effect of inhaled interferon-gamma. Critical care medicine 2002; 30 :1488-94.

11. Dries DJ, Jurkovich GJ, Maier RV, Clemmer TP, Struve SN, Weigelt JA, Stanford GG, Herr DL, Champion HR, Lewis FR, et al. Effect of interferon gamma on infection-related death in patients with severe injuries. A randomized, double-blind, placebo-controlled trial. Archives of Surgery 1994; 129 :103141; discussion 42.

12. Polk HC, Jr., Cheadle WG, Livingston DH, Rodriguez JL, Starko KM, Izu AE, Jaffe HS, Sonnenfeld G. A randomized prospective clinical trial to determine the efficacy of interferon-gamma in severely injured patients. Am J Surg 1992; 163 :191-6.

13. Wasserman D, Ioannovich JD, Hinzmann RD, Deichsel G, Steinmann GG. Interferon-gamma in the prevention of severe burn-related infections: a European phase III multicenter trial. The Severe Burns Study Group. Critical care medicine 1998; 26 :434-9.

14. Galbraith N, Walker S, Carter J, Polk HC, Jr. Past, Present, and Future of Augmentation of Monocyte Function in the Surgical Patient. Surgical infections 2016; 17 :563-9.

15. Xiao W, Mindrinos MN, Seok J, Cuschieri J, Cuenca AG, Gao H, Hayden DL, Hennessy L, Moore EE, Minei JP, Bankey PE, Johnson JL, Sperry J, Nathens AB, Billiar TR, West MA, Brownstein BH, Mason PH, Baker HV, Finnerty CC, Jeschke MG, Lopez MC, Klein MB, Gamelli RL, Gibran NS, Arnoldo B, Xu W, Zhang Y, Calvano SE, McDonald-Smith GP, Schoenfeld DA, Storey JD, Cobb JP, Warren HS, Moldawer LL, Herndon DN, Lowry SF, Maier RV, Davis RW, Tompkins RG, Inflammation, Host Response to Injury Large-Scale Collaborative Research P. A genomic storm in critically injured humans. J Exp Med 2011; 208 :2581-90.

16. Murphy T, Paterson H, Rogers S, Mannick JA, Lederer JA. Use of intracellular cytokine staining and bacterial superantigen to document suppression of the adaptive immune system in injured patients. Annals of surgery 2003; $238: 401-10$; discussion 10-1.

17. Licht AK, Schinkel C, Zedler S, Schinkel S, Faist E. Effects of perioperative recombinant human IFNgamma (rHuIFN-gamma) application in vivo on T cell response. J Interferon Cytokine Res 2003;23 :149-54.

18. Laudanski K, Miller-Graziano C, Xiao W, Mindrinos MN, Richards DR, De A, Moldawer LL, Maier RV, Bankey P, Baker HV, Brownstein BH, Cobb JP, Calvano SE, Davis RW, Tompkins RG. Cell-specific expression and pathway analyses reveal alterations in trauma-related human $\mathrm{T}$ cell and monocyte pathways. Proc Natl Acad Sci U S A 2006; 103 :15564-9.

19. Zhang Y, Li J, Lou J, Zhou Y, Bo L, Zhu J, Zhu K, Wan X, Cai Z, Deng X. Upregulation of programmed death- 1 on T cells and programmed death ligand-1 on monocytes in septic shock patients. Crit Care 2011;15 :R70. 
20. Galbraith NJ, O'Brien SJ, Walker SP, Gardner SA, Polk HC, Jr., Barnes SL. Temporal expression of circulating miRNA after severe injury. Surgery 2018; $164: 665-72$.

21. Li W, Tu J, Liu X, Yang W. Farnesyltransferase inhibitor FTI-277 inhibits PD-L1 expression on septic spleen lymphocytes and promotes spleen lymphocyte activation. Clinical and experimental immunology $2017 ; 190: 8-18$.

22. Patera AC, Drewry AM, Chang K, Beiter ER, Osborne D, Hotchkiss RS. Frontline Science: Defects in immune function in patients with sepsis are associated with PD-1 or PD-L1 expression and can be restored by antibodies targeting PD-1 or PD-L1. Journal of leukocyte biology 2016; $100: 1239-54$.

23. Shao R, Fang Y, Yu H, Zhao L, Jiang Z, Li CS. Monocyte programmed death ligand-1 expression after 3-4 days of sepsis is associated with risk stratification and mortality in septic patients: a prospective cohort study. Crit Care 2016; 20 :124.

24. Monaghan SF, Thakkar RK, Tran ML, Huang X, Cioffi WG, Ayala A, Heffernan DS. Programmed death 1 expression as a marker for immune and physiological dysfunction in the critically ill surgical patient.Shock $2012 ; 38: 117-22$.

25. Huang X, Venet F, Wang YL, Lepape A, Yuan Z, Chen Y, Swan R, Kherouf H, Monneret G, Chung CS, Ayala A. PD-1 expression by macrophages plays a pathologic role in altering microbial clearance and the innate inflammatory response to sepsis. Proc Natl Acad Sci U S A 2009;106 :6303-8.

26. Hotchkiss RS, Moldawer LL. Parallels between cancer and infectious disease. The New England journal of medicine 2014;371:380-3.

27. Monneret G, Gossez M, Venet F. Sepsis in PD-1 light. Crit Care 2016; 20 :186.

28. Drewry AM, Samra N, Skrupky LP, Fuller BM, Compton SM, Hotchkiss RS. Persistent lymphopenia after diagnosis of sepsis predicts mortality. Shock 2014; $42: 383-91$.

29. Patil NK, Luan L, Bohannon JK, Hernandez A, Guo Y, Sherwood ER. Anti-PD-L1 protects against infection with common bacterial pathogens after burn injury. Journal of leukocyte biology 2018;103 :23-33.

30. Zhang Y, Zhou Y, Lou J, Li J, Bo L, Zhu K, Wan X, Deng X, Cai Z. PD-L1 blockade improves survival in experimental sepsis by inhibiting lymphocyte apoptosis and reversing monocyte dysfunction. Crit Care 2010; 14 :R220.

31. Brahmamdam P, Inoue S, Unsinger J, Chang KC, McDunn JE, Hotchkiss RS. Delayed administration of anti-PD-1 antibody reverses immune dysfunction and improves survival during sepsis. Journal of leukocyte biology 2010; $88: 233-40$.

32. Chang K, Svabek C, Vazquez-Guillamet C, Sato B, Rasche D, Wilson S, Robbins P, Ulbrandt N, Suzich J, Green J, Patera AC, Blair W, Krishnan S, Hotchkiss R. Targeting the programmed cell death 1: programmed cell death ligand 1 pathway reverses T cell exhaustion in patients with sepsis. Crit Care 2014; 18 :R3.

33. Fallon EA, Biron-Girard BM, Chung CS, Lomas-Neira J, Heffernan DS, Monaghan SF, Ayala A. A novel role for coinhibitory receptors/checkpoint proteins in the immunopathology of sepsis. Journal of leukocyte biology 2018.

34. Hotchkiss RS, Monneret G, Payen D. Sepsis-induced immunosuppression: from cellular dysfunctions to immunotherapy. Nature reviews Immunology 2013; 13 :862-74.

35. Heinzelmann M, Polk HC, Jr., Chernobelsky A, Stites TP, Gordon LE. Endotoxin and muramyl dipeptide modulate surface receptor expression on human mononuclear cells. Immunopharmacology 2000;48 :117-28.

36. Galbraith NJ, Manek S, Walker S, Bishop C, Carter JV, Cahill M, Gardner SA, Polk HC, Jr., Galandiuk S. The effect of IkappaK-16 on lipopolysaccharide-induced impaired monocytes. Immunobiology 2017. 
37. Turrel-Davin F, Venet F, Monnin C, Barbalat V, Cerrato E, Pachot A, Lepape A, Alberti-Segui C, Monneret G. mRNA-based approach to monitor recombinant gamma-interferon restoration of LPS-induced endotoxin tolerance. Crit Care 2011; 15 :R252.

38. Cheng SC, Scicluna BP, Arts RJ, Gresnigt MS, Lachmandas E, Giamarellos-Bourboulis EJ, Kox M, Manjeri GR, Wagenaars JA, Cremer OL, Leentjens J, van der Meer AJ, van de Veerdonk FL, Bonten MJ, Schultz MJ, Willems PH, Pickkers P, Joosten LA, van der Poll T, Netea MG. Broad defects in the energy metabolism of leukocytes underlie immunoparalysis in sepsis. Nature immunology 2016; 17 :406-13.

39. Livingston DH, Loder PA, Gibson UE, Polk HC. Interferon gamma administration increases monocyte HLA-DR antigen expression but not endogenous interferon production. Archives of Surgery 1994;129 .

40. de Kleijn S, Langereis JD, Leentjens J, Kox M, Netea MG, Koenderman L, Ferwerda G, Pickkers P, Hermans PW. IFN-gamma-stimulated neutrophils suppress lymphocyte proliferation through expression of PD-L1.PLoS One 2013; 8 :e72249.

41. Rentenaar RJ, de Metz J, Bunders M, Wertheim-van Dillen PM, Gouma DJ, Romijn JA, Sauerwein HP, ten Berge IJ, van Lier RA. Interferon-gamma administration after abdominal surgery rescues antigen-specific helper T cell immune reactivity. Clinical and experimental immunology 2001; 125 :401-8.

42. Ou JN, Wiedeman AE, Stevens AM. TNF-alpha and TGF-beta counter-regulate PD-L1 expression on monocytes in systemic lupus erythematosus. Scientific reports 2012; 2 :295.

43. Yee D, Shah KM, Coles MC, Sharp TV, Lagos D. MicroRNA-155 induction via TNF-alpha and IFNgamma suppresses expression of programmed death ligand-1 (PD-L1) in human primary cells. J Biol Chem 2017;292:20683-93.

44. Payen D, Faivre V, Miatello J, Leentjens J, Brumpt C, Tissieres P, Dupuis C, Pickkers P, Lukaszewicz AC. Multicentric experience with interferon gamma therapy in sepsis induced immunosuppression. A case series. BMC infectious diseases 2019; 19 :931.

45. Francois B, Jeannet R, Daix T, Walton AH, Shotwell MS, Unsinger J, Monneret G, Rimmele T, Blood T, Morre M, Gregoire A, Mayo GA, Blood J, Durum SK, Sherwood ER, Hotchkiss RS. Interleukin-7 restores lymphocytes in septic shock: the IRIS-7 randomized clinical trial. JCI insight 2018; 3 .

46. Hotchkiss RS, Colston E, Yende S, Angus DC, Moldawer LL, Crouser ED, Martin GS, Coopersmith CM, Brakenridge S, Mayr FB, Park PK, Ye J, Catlett IM, Girgis IG, Grasela DM. Immune Checkpoint Inhibition in Sepsis: A Phase 1b Randomized, Placebo-Controlled, Single Ascending Dose Study of Antiprogrammed Cell Death-Ligand 1 Antibody (BMS-936559). Critical care medicine 2019; 47 :632-42.

47. Of men, not mice. Nature Medicine 2013; $19: 379$.

48. Moore FA, Moore EE, Poggetti R, McAnena OJ, Peterson VM, Abernathy CM, Parsons PE. Gut bacterial translocation via the portal vein: a clinical perspective with major torso trauma. The Journal of trauma 1991; 31 :629-36; discussion 36-8.

List of Figures 

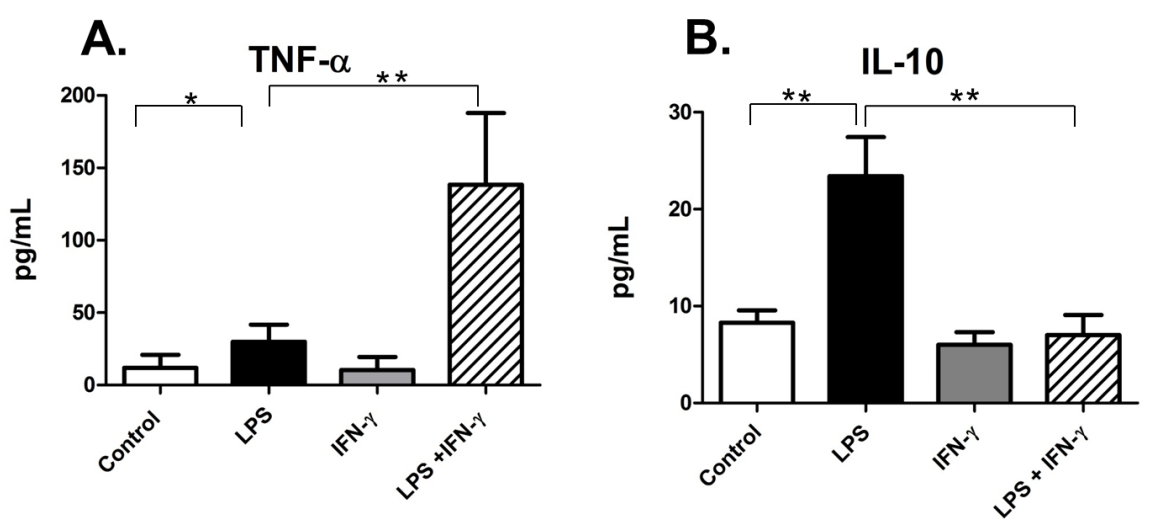

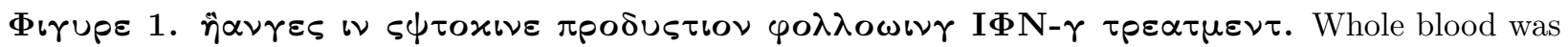
treated with $100 \mathrm{ng} / \mathrm{mL}$ of LPS, $100 \mathrm{ng} / \mathrm{mL}$ of interferon (IFN)- $\gamma$ or both for $18 \mathrm{~h}$. Plasma concentrations of (A) TNF- $\alpha$ and (B) IL-10 were determined by ELISA. Values are mean \pm S.E.M. N $=6$ for each condition. ${ }^{*} \mathrm{P}<0.05,{ }^{* *} \mathrm{P}<0.01$, Repeat Measures ANOVA with post-hoc Holms-Sidak test.

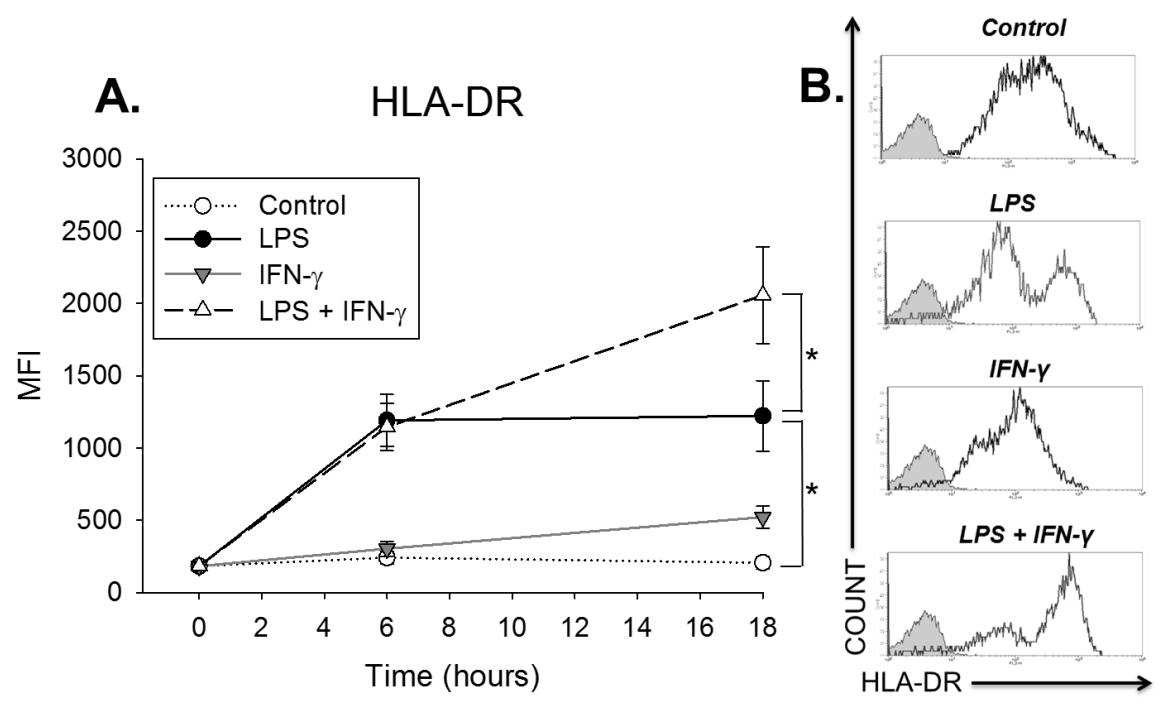

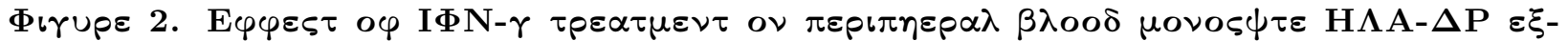
$\pi \rho \varepsilon \sigma \sigma \iota \boldsymbol{\nu}$. (A) Whole blood was treated with $100 \mathrm{ng} / \mathrm{mL}$ of LPS, $100 \mathrm{ng} / \mathrm{mL}$ of IFN- $\gamma$ or both. Surface monocyte HLA-DR expression assessed by FACS at $0 \mathrm{~h}, 6 \mathrm{~h}$ and $18 \mathrm{~h}$. Values are mean \pm S.E.M. $\mathrm{N}=6 .{ }^{*} \mathrm{P}$ $<0.05$, Repeat Measures ANOVA with post-hoc Holms-Sidak test. (B) Representative flow cytometry images with the control group shown in grey and each experimental condition shown without shading. A minimum

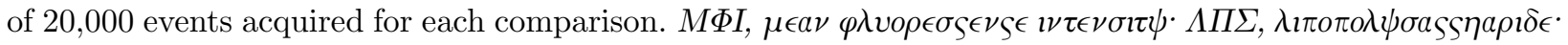
$I \Phi N-\gamma, \imath \nu \tau \in \rho \varphi \epsilon \rho o \nu-\gamma \alpha \mu \mu a$. 

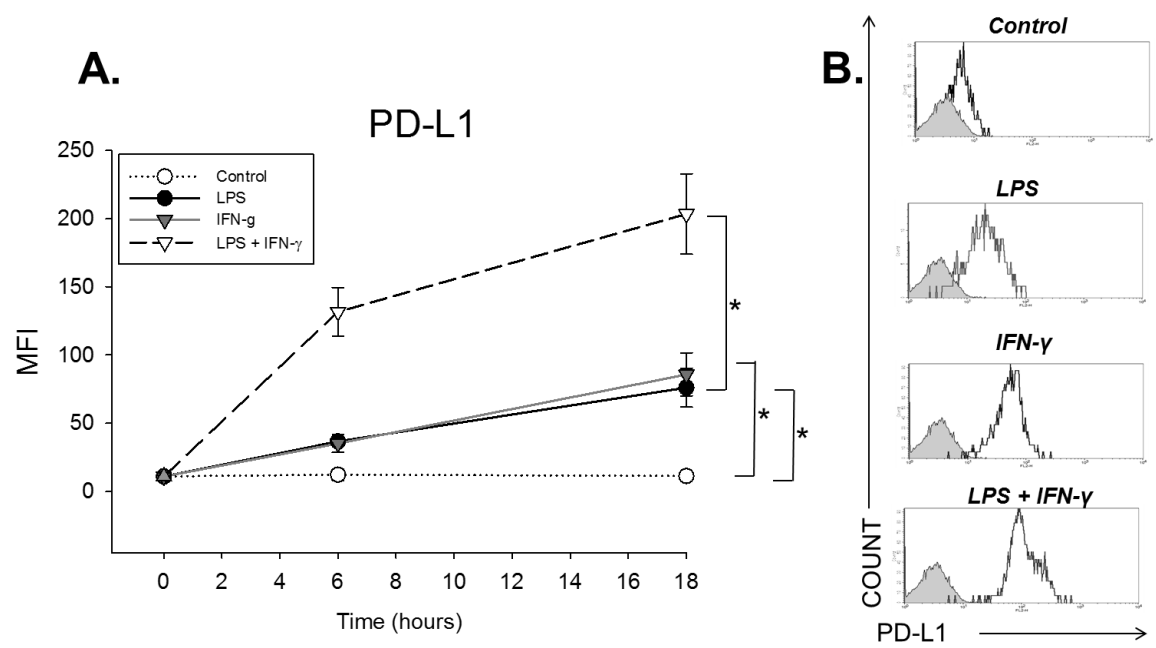

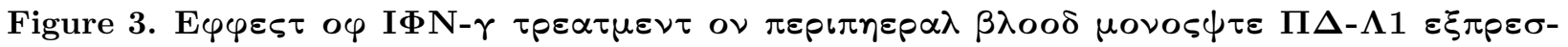

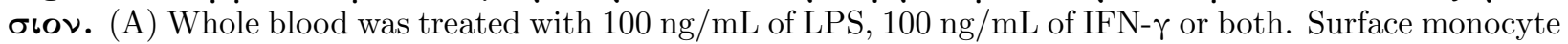
PD-L1 expression was measured by FACS at $0 \mathrm{~h}, 6 \mathrm{~h}$ and $18 \mathrm{~h}$. Values are mean \pm S.E.M. $\mathrm{N}=6$ at each time point. ${ }^{*} \mathrm{P}<0.05$, Repeat Measures ANOVA with post-hoc Holms-Sidak test. (B) Representative flow cytometry images with the control group shown in grey and each experimental condition shown without shading. A minimum of 20,000 events acquired for each comparison. $M \Phi I, \mu \epsilon a \nu \varphi \lambda v v_{\rho} \rho \sigma \varsigma \epsilon \nu_{\varsigma} \epsilon \imath \tau \tau \epsilon \nu \sigma \tau \psi \cdot \Lambda \Pi \Sigma$, $\lambda \imath \pi о \pi о \lambda \psi \sigma a \varsigma \varsigma \eta а \rho \imath \delta \epsilon \cdot I \Phi N-\gamma, \imath \nu \tau \epsilon \rho \varphi \epsilon \rho o \nu-\gamma \alpha \mu \mu a$. 
A.

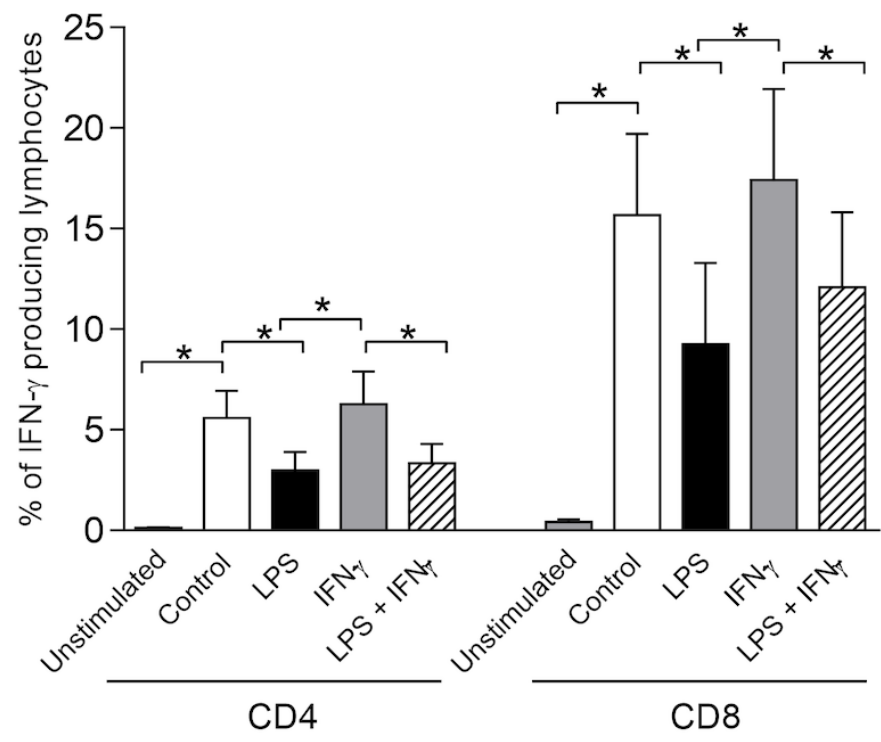

B.
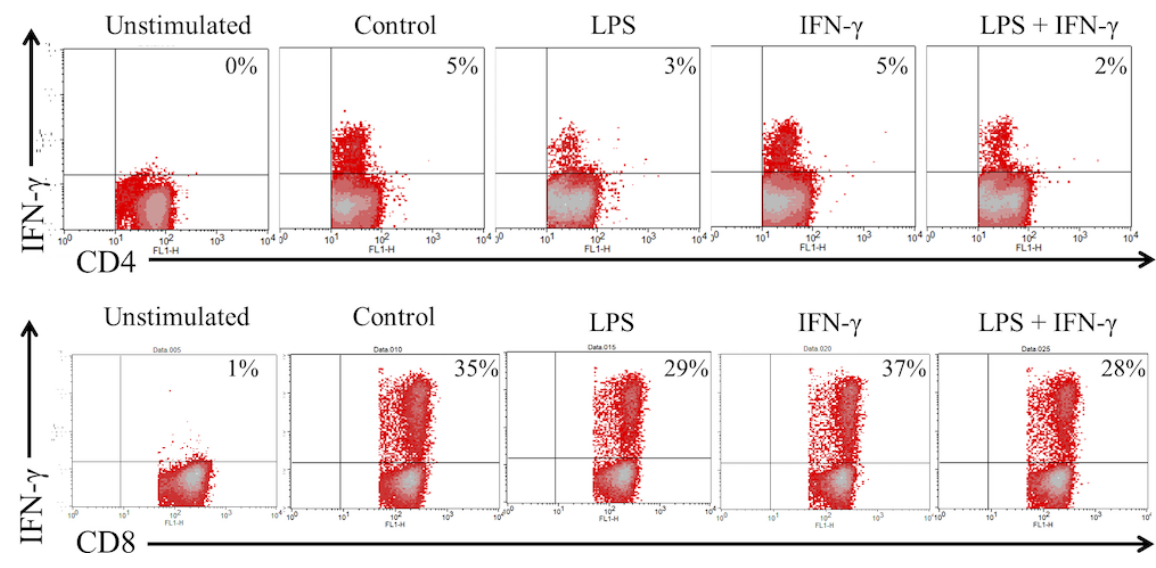

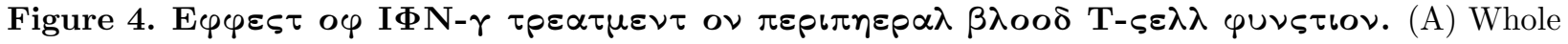
blood was treated with $100 \mathrm{ng} / \mathrm{mL}$ of LPS, $100 \mathrm{ng} / \mathrm{mL}$ of IFN- $\gamma$ or both. After $16 \mathrm{~h}$ of experimental conditions, PBMC's were isolated, washed then stimulated with PMA, ionomycin and Brefeldin A for 6 h. Intracellular IFN- $\gamma$ production was measured in CD4 and CD8 T-cells by FACS as a measure of T-cell activation. Values are mean \pm S.E.M. $\mathrm{N}=6$ for each condition. ${ }^{*} \mathrm{P}<0.05$, Repeat Measures ANOVA with post-hoc Holms-Sidak test. (B) Representative flow cytometry images with the control group shown in grey and each experimental condition shown without shading. A minimum of 20,000 events acquired for each

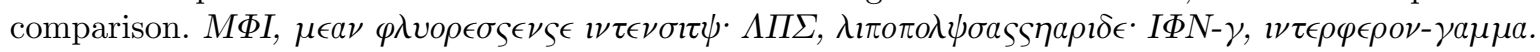




\begin{tabular}{|c|c|c|}
\hline \multicolumn{3}{|l|}{ Cellular effects } \\
\hline Function/marker & Study type & Reference \\
\hline$\uparrow \mathrm{HLA}-\mathrm{DR}$ & Clinical (trauma) & [12] \\
\hline$\uparrow$ TNF-a (LPS-induced) & Clinical (sepsis) & [9] \\
\hline$\downarrow$ IL-10 & Clinical (trauma) & [10] \\
\hline$\uparrow \mathrm{PD}-\mathrm{L} 1$ & $\begin{array}{l}\text { Experimental (ex-vivo) } \\
\text { Experimental } \\
\text { (human endotoxaemia) }\end{array}$ & $\begin{array}{l}{[36]} \\
{[40]}\end{array}$ \\
\hline Th1 phenotype & $\begin{array}{l}\text { Human (elective } \\
\text { surgery) }\end{array}$ & [17] \\
\hline $\begin{array}{l}\text { Equivalent T-cell } \\
\text { function }\end{array}$ & Experimental (ex-vivo) & * \\
\hline$\downarrow T$-cell proliferation & $\begin{array}{l}\text { Experimental } \\
\text { (human endotoxaemia) }\end{array}$ & [40] \\
\hline$\downarrow$ NK cells & Clinical (sepsis) & [44] \\
\hline $\begin{array}{l}\uparrow \text { miRNA-155 } \\
\text { expression }\end{array}$ & Experimental (ex-vivo) & [43] \\
\hline Increased glycolysis & Mixed & [38] \\
\hline
\end{tabular}

\begin{tabular}{|l|l|l|}
\hline \multicolumn{3}{|l|}{ Clinical effects } \\
\hline Outcome & Study type & Reference \\
\hline $\begin{array}{l}\text { Decreased operations } \\
\text { for infection after } \\
\text { trauma }\end{array}$ & RCT (trauma) & {$[12]$} \\
\hline $\begin{array}{l}\text { Decreased deaths } \\
\text { related to infection }\end{array}$ & RCT (trauma) & {$[11]$} \\
\hline $\begin{array}{l}\text { Decreased mortality } \\
\text { rate }\end{array}$ & $\begin{array}{l}\text { Non- } \\
\text { randomized trial } \\
\text { (sepsis) }\end{array}$ & {$[9]$} \\
\hline $\begin{array}{l}\text { No effect on infection } \\
\text { or death }\end{array}$ & RCT (burns) & {$[13]$} \\
\hline
\end{tabular}

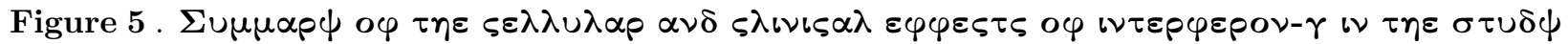

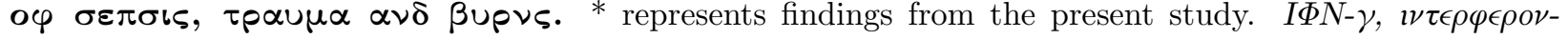

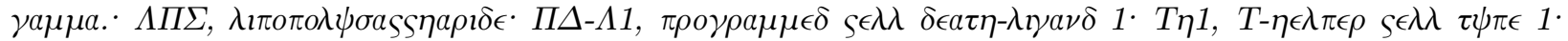

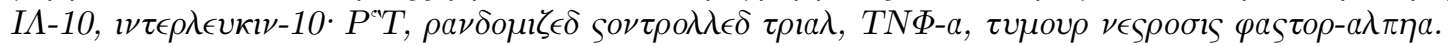

